\title{
Effects of Pulmonary Rehabilitation on Lung Functions In Patients with COPD
}

\author{
Mohammad Nesar Uddin Ahmed ${ }^{1}$, Shelina Begum ${ }^{2}$, Shamima Sultana $^{3}$, Taskina Ali ${ }^{4}$
}

\begin{abstract}
Background: The importance of pulmonary rehabilitation (PR) as a therapeutic measure for COPD patients is well known. Objective: To evaluate the effects of PR program by pursed lip breathing (PLB) and diaphragmatic breathing (DB) on $\mathrm{FVC}, \mathrm{FEV}_{1}, \mathrm{FEV}_{1} / \mathrm{FVC}$ ratio in male patients with moderate stable COPD. Methods: This prospective study was conducted in the Department of Physiology, BSMMU, Dhaka from July 2010 to June 2011 on 116 male stable moderate COPD patients aged 50 to 65 years. They were enrolled from the out patient department of the Department of Medicine of BSMMU and NIDCH Dhaka. They were grouped as control (56 patients without PR) and experimental (60 patients with PR). The experimental patients were advised to perform PR program for 30 minutes duration per session at home twice daily, for consecutive 60 days along with the standard drug treatment of COPD. On the contrary, the control patients were advised to continue their standard drug treatment alone for consecutive 60 days. For the assessment of spirometric lung function status, $\mathrm{FVC}, \mathrm{FEV}_{1}, \mathrm{FEV}_{1} / \mathrm{FVC}$ ratio of all subjects were recorded on day 0 and day 60 for both the group by a portable digital MicroDL Spirometer and the statistical analysis was done by independent sample ' $t$ ' test and paired Student's ' $t$ ' test. Results: FVC and $\mathrm{FEV}_{1}$ value were significantly increased in comparison to the control patients after 60 days of follow up. On the other hand, post exercise value of $\mathrm{FEV}_{1} / \mathrm{FVC}$ ratio was decreased but it was not statistically significant. Conclusion: The study reveals improvement of lung functions with this sort of combination of PR program in stable COPD patients.
\end{abstract}

Key words: Pulmonary rehabilitation, COPD, Spirometry, $\mathrm{FVC}, \mathrm{FEV}_{1}, \mathrm{FEV}_{1} / \mathrm{FVC}$ ratio.

Bangladesh Soc Physiol. 2013, December; 8(2): 70-76 For Authors Affiliation, see end of text.

http://www.banglajol.info/index.php/JBSP

\section{Introduction}

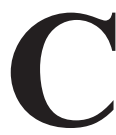

Chronic Obstructive Pulmonary Disease (COPD) is one of the major causes of chronic morbidity and mortality throughout the world. ${ }^{1}$ Many people suffer from the disease for years and die too early from its complications. It is the fourth leading cause of death in adults of United States and also projected to be the third by 2020. ${ }^{2,3,4}$ According to Global Initiative for

Received; June 2013 Accepted : September 2013
Chronic Obstructive Lung Disease (2008), COPD is a preventable and treatable disease. ${ }^{1}$ However, once developed this disease along with its comorbidities can not be cured, though its progression and morbidity can be reduced. ${ }^{1}$

The pulmonary component of COPD is characterized by airflow limitation which is not fully reversible and usually progressive. ${ }^{1}$ Chronic airflow limitation in COPD is caused by a mixture 
of small airways disease (obstructive bronchiolitis) and parenchymal destruction (emphysema) the relative contributions of which vary from person to person. Chronic inflammation causes structural changes and narrowing of the small airways resulting decrement in ventilatory variables. ${ }^{1}$

Spirometry has been suggested as the method of assessing lung function by measuring the volume of air that a person can expel from the lungs after a maximal inspiration. ${ }^{5}$ Again, GOLD (2008) stated that spirometry is the best way of making a definitive diagnosis of COPD. ${ }^{1}$ Although spirometry does not fully capture the impact of COPD on a patient's health, it remains the gold standard for diagnosing the disease and monitoring its progression. ${ }^{1}$ It has also been proposed as the best standardized, most reproducible and most objective measurement within the available maneuver for any airflow limitation. ${ }^{1}$ It has been suggested by different investigators abroad that, the ventilatory functions of the lung such as forced vital capacity (FVC), forced expiratory volume in $1^{\text {st }}$ second $\left(\mathrm{FEV}_{1}\right), \mathrm{FEV}_{1} / \mathrm{FVC}$ ratio can be assessed by spirometry. 6,8

Pulmonary rehabilitation (PR) is an evidencebased, multidisciplinary and comprehensive intervention for patients with chronic respiratory diseases who are symptomatic and often have decreased daily life activities. ${ }^{9}$ Integrated into the individualized treatment of the patient, PR has been designed to reduce symptoms, optimize functional status, increase participation and reduce health care costs through stabilizing or reversing systemic manifestation of the disease ${ }^{9}$. According to GOLD (2008), principal goals of $\mathrm{PR}$ are to reduce the symptoms, to improve quality of life, and to increase the physical and emotional participation in everyday activities. ${ }^{1}$
To accomplish these goals, pulmonary rehabilitation covers a range of non-pulmonary problems that may not be adequately addressed by medical therapy for COPD. The minimum length of an effective rehabilitation program has been suggested as 6 (six) weeks, though longer would the program, more effective would be the results. $^{1}$

Medicines might have a limited role in improving these ventilatory variables in COPD patients. However, rehabilitation programs such as pursed lip breathing and diaphragmatic breathing (breathing exercise) have been found to improve ventilatory variables. ${ }^{10}$ In comparison to a hospital setting home based rehabilitation has been preferred, since it is more convenient for patients as they stay at home, remain in touch with their families and also apply training in their life style. ${ }^{10}$

In different prospective studies abroad improvement in $\mathrm{FVC}_{1} \mathrm{FEV}_{1}, \mathrm{FEV}_{1} / \mathrm{FVC} \%$ were found by different investigators in patients with stable COPD both before and after administration of different component of PR program such as breathing strategies and lower extremity endurance training. ${ }^{10-14}$

However, with the best of our knowledge no study has yet been done in Bangladesh to observe the effects of combination of more than one component of PR program on lung functions in stable COPD patients. Therefore, on the basis of this background, the present study has been designed to evaluate the effects of pursed lip breathing and diaphragmatic breathing (breathing exercise) of PR program on spirometric lung functions in male patients with moderate stable COPD.

\section{Methods}

This prospective study with exercise intervention was carried out in the Department 
of Physiology, Bangabandhu Sheikh Mujib Medical University (BSMMU), Shahbag, Dhaka from July 2010 to June 2011. A total number of 116 male stable (without any exacerbation for last 4 weeks $^{15}$ ) moderate COPD (Postbronchodilator $\mathrm{FEV}_{1} / \mathrm{FVC}<0.70$ and $\mathrm{FEV}_{1}$ $<80 \%$ but e" $50 \%$ of predicted ${ }^{1}$ ) patients aged 50 to 65 years were selected from the Medicine Out Patient Department (Respiratory Wing) of BSMMU and the Department of Medicine of National Institute of Diseases of the Chest and Hospital (NIDCH) by systematic random sampling Mohakhali, Dhaka. Out of this, 56 COPD patients were not given PR program and act as control group (Group A), 60 patients were given PR program and act as study group (Group $\mathrm{B})$ and designated as $\mathrm{A}_{1}$ and $\mathrm{B}_{1}(\mathrm{On}$ day 0$)$ and $A_{2}$ and $B_{2}(O n$ day 60$)$, respectively. The study protocol was approved by Ethical Review Committee (ERC) of BSMMU. COPD patients of both group were similar in terms of age, height, duration of COPD, duration of smoking ${ }^{16}$, socioeconomic status ${ }^{17}$ and occupation $^{16}$. Subjects with the history of bronchial asthma, bronchiectasis, respiratory failure, pneumothorax, pleural effusion, pulmonary tuberculosis, pulmonary fibrosis, pneumonectomy or pulmonary lobectomy etc ${ }^{18}$ any cardiovascular diseases ${ }^{18}$, diabetes mellitus (Fasting plasma glucose $>7 \mathrm{mmol} / \mathrm{dl}^{19,20,21}$ ), irritable bowel syndrome ${ }^{22}, \mathrm{SLE}^{23,24}$, systemic hypertension (SBP e" 140 and DBP e" $90 \mathrm{~mm}$ of $\mathrm{Hg}^{25}$ ), any malignancy or renal disease (Serum creatinine $>1.36 \mathrm{mg} / \mathrm{dl}^{26}$ ), were excluded from the study. Pulmonary Rehabilitation (PR) program included pursed lip breathing and diaphragmatic breathing (breathing exercise ${ }^{10}$ ) for 30 minutes duration per session and were performed at home twice daily, for consecutive 60 (Sixty) days along with the standard drug treatment of COPD. In the technique of pursed lip breathing, patients inhaled through the nose with mouth closed, and then exhaled through mouth with lips pursed tightly ${ }^{10}$. The exhalation was twice as long as the inhalation. In the technique of diaphragmatic breathing, the patients were asked to exhale slowly through pursed lips while drawing the abdomen inward, and inhale slowly through the nose so that the abdomen would expand outward ${ }^{10}$.

After selection, all the patients were thoroughly informed about the aim, objectives and procedure of the study and were encouraged for their voluntary participation. Then an informed written consent was taken from each subject. A detail personal, medical, family, socioeconomic, occupational and drug history were recorded in a preformed questionnaire and thorough physical examinations were done and documented. For the assessment of spirometric lung function status, FVC, $\mathrm{FEV}_{1}, \mathrm{FEV}_{1} / \mathrm{FVC}$ ratio of all subjects were recorded by a portable digital MicroDL Spirometer. All these variables were measured in both the groups, on the very first day of the study and also at $60^{\text {th }}$ days after the exercise. Data were expressed as mean \pm SD of percentage of the predicted value $(\% \mathrm{PV})$ and were statistically analyzed by SPSS (Version 16.0) using Chi-square test, independent sample ' $t$ ' test and paired student's ' $t$ ' test, as applicable. In the interpretation of results, pd"0.05 was accepted, as level of significance.

\section{Results}

Sociodemographic characteristics of different groups as shown in Table I.

After 60 days follow up, mean $\mathrm{FVC}, \mathrm{FEV}_{1}$ were increased in both the groups, but the increment were significant only in the experimental group (Table II).

On the other hand, mean $\mathrm{FEV}_{1} / \mathrm{FVC}$ ratio was almost similar in both the groups after 60 days follow up (Table II). 
Table I: Sociodemographic characteristics of different groups ( $\mathrm{n}=116)$

\begin{tabular}{lccc}
\hline Parameters & $\begin{array}{c}\text { Group A } \\
(\mathrm{n}=56)\end{array}$ & $\begin{array}{c}\text { Group B } \\
(\mathrm{n}=60)\end{array}$ & P value \\
\hline Age (years) & $58.91 \pm 4.05$ & $58.58 \pm 4.12$ & $0.667^{\mathrm{ns}}$ \\
& $(50-65)$ & $(50-65)$ & \\
Height (meters) & $1.655 \pm 0.03$ & $1.651 \pm 0.03$ & $0.458^{\mathrm{ns}}$ \\
& $(1.58-1.72)$ & $(1.57-1.71)$ & \\
Duration of COPD & $3.04 \pm 1.12$ & $3.41 \pm 1.22$ & $0.090^{\mathrm{ns}}$ \\
(years) & $(0.5-5)$ & $(1-5)$ & \\
Duration of smoking & $15.41 \pm 4.16$ & $16.80 \pm 4.38$ & $0.075^{\mathrm{ns}}$ \\
(pack years) & $(11-25)$ & $(11-25)$ & \\
Socioeconomic & $1.63 \pm 0.78$ & $1.88 \pm 0.83$ & $0.298^{\mathrm{ns}}$ \\
statue (score) & $(1-4)$ & $(1-4)$ & \\
Occupation (score) & $2.04 \pm 1.06$ & $2.37 \pm 1.06$ & $0.232^{\mathrm{ns}}$ \\
& $(1-4)$ & $(1-4)$ & \\
\hline
\end{tabular}

Data were expressed as mean \pm SD. Figures in parentheses indicate ranges $\mathrm{a}=$ independent sample ' $\mathrm{t}$ ' test, $\mathrm{b}=$ Chi-square test $\left(\chi^{2}\right)$, applicable for A vs B.

Group A : Stable COPD patients without PR (control), Group B : Stable COPD patients with PR (experimental) $\mathrm{n}=$ number of subjects, $\mathrm{ns}=$ non significant

Table II: FVC, $\mathrm{FEV}_{1}, \mathrm{FEV}_{1} / \mathrm{FVC}$ ratio in different groups with different duration (n=116)

\begin{tabular}{|c|c|c|c|c|}
\hline$\overline{\text { Groups }}$ & $\begin{array}{l}\text { Measurement on } \\
\text { different duration }\end{array}$ & FVC & $\mathrm{FEV}_{1}$ & $\begin{array}{c}\mathrm{FEV}_{1} / \mathrm{FVC} \\
\text { ratio }\end{array}$ \\
\hline A & $\mathrm{A}_{1}$ & $97.89 \pm 8.74$ & $64.18 \pm 5.87$ & $65.64 \pm 3.26$ \\
\hline \multirow[t]{3}{*}{$(n=56)$} & (on day 0 ) & $(80-112)$ & $(54-75)$ & $(57-69)$ \\
\hline & $\mathrm{A}_{2}$ & $98.77 \pm 7.52$ & $64.57 \pm 6.18$ & $65.33 \pm 3.01^{ף}$ \\
\hline & (on day 60 ) & $(84-113)$ & $(52-74)$ & $(59-70)$ \\
\hline B & $\mathrm{B}_{1}$ & $96 \pm 7.68^{\#}$ & $62.43 \pm 5.96^{\#}$ & $65.07 \pm 3.88^{\#}$ \\
\hline \multirow[t]{3}{*}{$(n=60)$} & (on day 0 ) & $(81-110)$ & $(53-74)$ & (56-69) \\
\hline & $\mathrm{B}_{2}$ & $100.02 \pm 8.75^{* * * * ; “ \cdots}$ & $64.70 \pm 6.12^{* * * * ; ; “ \cdots}$ & $64.79 \pm 4.14^{*}, “ \cdots$ \\
\hline & (on day 60 ) & (82-114) & (55-75) & (56-71) \\
\hline
\end{tabular}

Data were expressed as mean $\pm \mathrm{SD}$ of $\%$ of $\mathrm{PV}$. Figures in parentheses indicate ranges.

$\mathrm{a}=$ independent sample ' $\mathrm{t}$ ' test, $\mathrm{c}=$ paired student's ' $\mathrm{t}$ ' test.

Group A : Stable COPD patients without PR (control), Group B : Stable COPD patients with PR (experimental)

$\mathrm{n}=$ number of subjects, $* * * *=$ significant $(\mathrm{p}<0.001)$

$\#,<\&,{ }^{*}, “$ “ $=$ non significant

$\mathrm{A}_{1}$ vs $\mathrm{B}_{1}{ }^{\mathrm{a}=}=\#, \mathrm{~A}_{1}$ vs $\mathrm{A}_{2}{ }^{\mathrm{b}}=$ q, $\mathrm{B}_{1}$ vs $\mathrm{B}_{2}^{\mathrm{b}}=*, \mathrm{~A}_{2}$ vs $\mathrm{B}_{2}^{\mathrm{a}}=$ ، 


\section{Discussion}

The present study shows significant improvement of FVC and $\mathrm{FEV}_{1}$ in pulmonary rehabilitated COPD patients after giving breathing exercise. But these value were almost comparable in the medicine treated COPD patients. In addition, $\mathrm{FEV}_{1} / \mathrm{FVC}$ ratio was almost similar in both the groups of COPD patients. Similar observation were reported by several investigators. ${ }^{11-14}$

From our study, the exact mechanisms of the benefit of PR program on lung functions in stable COPD patients could not be elucidated. It has been suggested that, long standing alveolar hypoventilation and dyspnea in the COPD patients may cause increased work of breathing, hypoxia induced decreased ATP production and increased energy expenditure followed by skeletal muscle wasting in these groups of patients. $^{27-30}$ On the other hand, expiratory airflow limitation due to decrease elastic fibres in the alveolar walls and airways have also been suggested as an important contributory factor for lung hyperinflation in this group of patients. As a consequence, there may be increase in inspiratory airflow resistance followed by derangement of ventilatory variables. ${ }^{31-34}$

It has also been suggested, the first component of PR program that is, regular pursed lip breathing has been suggested to decrease the amount of the trapped air in the lungs followed by decreased work of breathing ${ }^{35}$ as well as relief of dyspnea. ${ }^{35,36}$ Moreover, regular diaphragmatic breathing (another important component of our PR program) along with pursed lip breathing have also been proposed to be a cause of strengthening of the diaphragm and abdominal muscles followed by decrement in energy utilization for breathing. ${ }^{37,38}$ As a consequence, coordinated movement of the diaphragm during respiration may produce improvement of the lung function in this study.

\section{Conclusion}

From this study, it may be concluded that lung functions may improve after regular PR program in male patients with moderate stable COPD.

\section{Acknowledgement}

Authors of this study are thankful to the authority of the Department of Medicine (Respiratory wing), BSMMU and the Department of Medicine, $\mathrm{NIDCH}$, for their nice cooperation during sample collection and also thankful to the study subjects for their active and enthusiastic participation.

\section{Author affiliations}

1. *Mohammad Nesar Uddin Ahmed, Assistant professor, Department of Physiology, Jahurul Islam Medical College, Bajitpur, Kishoregonj, Email: nuddin301@gmail.com

2. Shelina Begum, Professor and Chairman, Department of Physiology, Bangabandhu Sheikh Mujib Medical University (BSMMU), Shahbag, Dhaka., Email: shelina1985@gmail.com

3. Shamima Sultana, Medical Officer, Department of Physiology, Bangabandhu Sheikh Mujib Medical University (BSMMU), Shahbag, Dhaka, Email:

4. Taskina Ali, Associate professor, Department of Physiology, Bangabandhu Sheikh Mujib Medical University (BSMMU), Shahbag, Dhaka, Email: taskinadr@gmail.com

*For correspondence

\section{References}

1. Global Initiative for Chronic Obstructive Lung Disease. Global strategy for the diagnosis, management and prevention of COPD. NIH Publication; 2008.

2. Sabit R, Botton CE, Edward PH, pettit RJ, Evans WD, McEniery CM, Wilkinson IB, Cockcroft JR, Shale DJ. Arterial stiffness and osteoporosis in chronic obstructive pulmonary disease. Am J Respir Crit Care Med. 2007; 175: 1259-1265.

3. Eickhoff P, Valipour A, Kiss D, Schreder M, Cekici L, Geyer K, Kohansal R \& Burghuber OC. Determinants of systemic vascular function in patients with stable Chronic Obstructive Pulmonary Disease. Am J Respir Crit Care Med. 2008; 178: 1211-1218.

4. Finkelstein J, Cha E \& Scharf SM. Chronic Obstructive Pulmonary disease as an independent 
risk factor for cardiovascular morbidity. Int $\mathrm{J}$ Chron Obstruct Pulmon Dis. 2009; 4: 337-349.

5. Hassan MR, Hossain MA, Mahmud AM, Kabir ARML, Amin MR, Rahman MM, Ahmad MM, Bennoor KS, Habib GMM, Alam MR, Khan MAS, Huq AKMS, editors. Bangladesh Lung Health Manual. $1^{\text {st }}$ ed. Bangladesh Lung Foundation; October 2010. p2-6.

6. Ruppel G. Manual of pulmonary function testing. $3^{\text {rd }}$ ed. St. Louis: Mosby Year book Company; 1982. p27-49.

7. Hyatt RE, Scanlon PD, Nakamura M. Interpretation of Pulmonary Function tests: A Practical Guide. $3^{\text {rd }}$ ed. Philadelphia: Lippincott Williams \& Wilkins; 2009. 25p.

8. Mehrparvar AH, Mirmohammadi SJ, Sohrabi MM. Spirometric indices after bronchodilator test in obstructive lung disease. Acta Medica Iranica. 2009; 48(4): 226-230.

9. Nici L, Donner C, Wouters E, Zuwallack R, Ambrosino N, Bourbeau J, Carone M, Celli B, Engelen M, Fahy B, Garvey C, Goldstein R, Gosselink R, Lareau S, Maclntyre N, Maltais F, Morgan M, O’Donnell D, Prefault C, Reardon J, Rochester C, Schols A, Singh S, Troosters T. American Thoracic Society/ European Respiratory Society statement on pulmonary rehabilitation. Am J Respir Crit Care Med. 2006; 173: 1390-1413.

10. Singh V, Khandelwal DC, Khandelwal R, Abusaria S. Pulmonary rehabilitation in patients with chronic obstructive pulmonary disease. Indian Chest Dis Allied Sci. 2002; 45: 13-17.

11. Carter R, Nicotra B, Clark L, Zinkgraf S, Williams J, Peavler M, Fields S, Berry J. Exercise conditioning in the rehabilitation of patients with chronic obstructive pulmonary disease. Arch Phys Med Rehabil. 1988 Feb; 69(2): 118-122.

12. Quingang L, Ping H, Xiaohong J. Effects of respiratory training on the lung function of COPD patients. Chin J Rehabil. 1999; 01: 13.

13. Sun JX, Yin MX, Shao H, Li ZS, Li SW. Effects of respirarory muscle gymnastics on lung function and quality of life in the old patients with chronic obstructive pulmonary disease. Chin J Rehabil. 2003; 27: 23 .

14. Rejbi IBC, Trabelsi Y, Chouchene A, Turkia WB, Saad HB, Zbidi A, Kerken A, Tabka Z. Changes in six-minute walking distance during pulmonary rehabilitation in patients with COPD and in healthy subjects. Int J Chron Obstruct Pulmon Dis. 2010; 5: 209-215.

15. McAllister DA, Maclay JD, Mills NL, Mair G, Miller J, Anderson D, Newby DE, Murchison JT, MacNee William. Arterial Stiffness Is Independently Associated With Emphysema Severity in Patients with Chronic Obstructive Pulmonary Disease. Am J Respir Crit Care Med. 2007; 176:1208 -1214.

16. Ali T, Begum N, Hassan MR, Bennoor KS. Effect of dietary modifications on some aspects of anthropometry and pulmonary functions in patients with chronic obstructive pulmonary disease. Bangladesh Journal of Physiology and Pharmacology (ISSN 1561-1566). 2003 Jan/Jul; 19(1/2): 24-27.

17. Mithun S. Comparative study of cardiac autonomic nerve function status by heart rate variability between sedentary and heavy workers. [Thesis] [Dhaka (Bangladesh)]: BSMMU. 2009.

18. Reid PT, Innes JA. Respiratory disease. In: Colledge NR, Walker BR, Ralston SH, editors. Davidson's principles and practice of medicine. $21^{\text {st }}$ ed. China: Elsevier Limited; 2010. p642-730.

19. WHO Definition, Diagnosis and Classification of Diabetes Mellitus and its complication. Report of a WHO Consultation. Geneva: WHO; 1999.

20. John C, Pickup, Williams G. In: Text book of diabetes, $3^{\text {rd }}$ ed. Blackwell science; 2003. p2.1-2.13.

21. Frier BM, Fisher M. Diabetes mellitus. In: College NR, Walker BR, Ralston SH, editors. Davidson's Principles and Practice of Medicine. Churchil Livingstone: Elsevier; 2010. p796-833.

22. Clark C, DeLegge M. Irritable bowel syndrome: a practical approach. Nutr Clin Pract. 2008; 23: 263267.

23. Hahn BH. Systemic Lupus Erythematosus. In: Kasper D, Braunwald E, Fauc AS, Hausen SL, Longo DL. editors. Harrison's Principles of Internal Medicine. NY: MC Graw-Hill; 2005. p1960-1967.

24. Gill LM, Quisel AM, Rocca PV, Walters DT. Diagnosis of Systemic Lupus Erythematosus. Am Fam Physician. 2003; 68(11) 2179-2187.

25. Newby DE, Grubb NR, Bradbury A. Cardiovascular disease. In: Colledge NR, Walker BR, Ralston SH, editors. Davidson's principles and practice of medicine. $21^{\text {st }}$ ed. China: Elsevier Limited; 2010. $606 \mathrm{p}$. 
26. Walker SW. Laboratory reference rate. In: College NR, Walker BR, Ralston SH, editors. Davidson's Principles and Practice of Medicine. Churchil Livingstone: Elsevier; 2010. p230-251.

27. Rennie MJ, Edwards RH, Emery PW, Halliday D, Lundholm K, Millward DJ. Dpressed protein synthesis is the dominant characteristic of muscle wasting and cachexia. Clin Physiol. 1983; 3: 387398.

28. Bigard AX, Sanchez H, Birot O, Serrurier B. Myosin heavy chain composition of skeletal muscles in young rats growing under hypobaric hypoxia conditions. J Appl Physiol. 2000; 88: 479-486.

29. Jagoe RT, Goldberg AL. What do we really know about the ubiquitin-proteasome pathway in muscle atrophy? Curr Op Clin Nutr Metab Care. 2001; 4: 183-190.

30. Jagoe RT, Engelen MPKJ. Muscle wasting and changes in muscle protein metabolism in chronic obstructive pulmonary disease. Eur Respir J. 2003; 22: $52-63$

31. Culpitt SV, Rogers DF, Traves SL, Barnes PJ, Donnelly LE. Sputum matrix metalloproteases: comparison between chronic obstructive pulmonary disease and asthma. Respir Med. 2005; 99: 703710 .
32. Demedts IK, Morel- Montero A, Lebecque S, Pacheco Y, Cataldo D, Joos GF, Pauwelst RA, Brusselle GG. Elevated MMP-12 protein levels in induced sputum from patients with COPD. Thorax. 2006; 61: 196-201

33. Black PN, Ching PST, Beaumont B, Ranasinghe S, Taylor G, Merrilees MJ. Changes in elastic fibres in the small airways and alveoli in COPD. Eur Respir J. 2008; 31: 998-1004.

34. Guyton AC, Hall JE. Textbook of Medical Physiology. 12 $2^{\text {th }}$ ed. Singapore: Saunders Elsevier; 2011. p465-523.

35. Ingram RM, Schilder DP. Effect of pursed lips expiration on the pulmonary pressure-flow relationship in obstructive lung disease. Am Rev Respir Dis. 1967; 96: 381-388.

36. Mueller RE, Petty TL, Filley GF. Ventilation and arterial blood gas changes induced by pursed lips breathing. J Appl Physiol. 1970; 28: 784-789.

37. Sackner MA. Diaphragmatic Breathing Exercises. Therapy in Chronic Obstructive Pulmonary Disease. JAMA. 1975; 231(3): 295.

38. Criner GJ, Celli BR. Effect of unsupported arm exercise on ventilatory muscle recruitment in patients with severe chronic airflow obstruction. Am Rev Respir Dis. 1988; 138: 856-861. 